\title{
Poultry fat decreased fatty acid transporter protein mRNA expression and affected fatty acid composition in chickens
}

\author{
Jianmin Yuan, Bingkun Zhang and Yuming Guo*
}

\begin{abstract}
Background: A study was undertaken to examine the effects of poultry fat (PF) compared with those of soybean oil (SBO) on intestinal development, fatty acid transporter protein (FATP) mRNA expression, and fatty acid composition in broiler chickens. A total of 144 day-old male commercial broilers were randomly allocated to 2 treatment groups (6 replicates of 12 chicks for each treatment) and fed isocaloric diets containing 3.0\% PF or 2.7\% $\mathrm{SBO}$ at 0 to $3 \mathrm{wk}$ and $3.8 \% \mathrm{PF}$ or $3.5 \% \mathrm{SBO}$ at 4 to 6 wk, respectively.

Results: PF had no influence on intestinal morphology, weight, or DNA, RNA, or protein concentrations at 2, 4, and 6 wk of age. However, compared with SBO, PF significantly decreased FATP mRNA abundance at 4 wk $(P=0.009)$ and 6 wk of age $(P<0.001)$; decreased liver fatty acid-binding protein (L-FABP) mRNA abundance at 6 wk of age $(P=0.039) ;$ and decreased $C 18: 2(P=0.015), C 18: 3(P<0.001), C 20: 2(P=0.018), \Sigma$-polyunsaturated fatty acids ( $\Sigma$-PUFA) $(P=0.020)$, and the proportion of PUFA $(P<0.001)$ in the intestinal mucosa and decreased $C 18: 2$ $(P=0.010), C 18: 3(P<0.001), C 20: 2(P<0.001), \Sigma$-PUFA $(P=0.005)$, and the proportion of PUFA $(P<0.001)$ in breast muscle at 6 wk of age.
\end{abstract}

Conclusions: PF decreases FATP and L-FABP mRNA expression and decreased the proportion of PUFA in the intestinal mucosa and breast muscle.

Keywords: Breast muscle, FATP mRNA, Fat type, Intestine, L-FABP mRNA

\section{Background}

As an organ of nutrient absorption, the small intestine is very important for animals. The capacity to absorb nutrients depends mainly on the development of the intestinal mucosa. A previous study showed that morphological characteristics of the small intestinal mucosa are affected by diet [1]. Dietary lipids could affect intestinal morphology [2-4], influencing the fatty acid (FA) composition of the apical enterocyte membrane [5] and the fluidity of brush border membranes [6]. This in turn could alter the transportation and diffusion of certain nutrients across the intestine [7].

Poultry fat (PF), an available ingredient source, has been widely used as an energy source in swine feeds. A previous study showed that PF appeared to be more efficiently utilized than swine fat for both body weight (BW)

\footnotetext{
*Correspondence: guoym9899@yahoo.com.cn

State Key Laboratory of Animal Nutrition, College of Animal Science and Technology, China Agricultural University, Beijing 100193, P. R. China
}

gain and the production of carcass energy [8] and did not influence swine performance compared with soybean oil (SBO) [9]. However, few data exist on the effect of PF on the development of intestinal structure and on the absorption and utilization of FA compared with other animal fats or plant oil.

Recently, there has been an increasing interest in improving the quality of meat. Flavor, which is easily perceived by the consumer, is an important evaluation factor of meat quality. Previous studies showed that dietary fat could affect the FA composition in animals. PF increased linoleic acid and decreased oleic acid contents in the longissimus muscle of pigs compared with beef tallow [10]. Apple et al. [9] showed that PF decreased the polyunsaturated FA (PUFA) content and PUFA to saturated FA (SFA) ratio in the longissimus muscle of pigs compared with SBO. Another previous study showed that the FA composition in breast muscle of broilers was associated with liver FA-binding protein (L-FABP) mRNA expression 
in intestinal mucosa [11], and FABP expression in the small intestine could be regulated by FA [12]. However, little attention has been given to the effect of PF on the FA composition and function of the intestines in broilers. The aim of the present study was to evaluate the effects of PF on the development of intestinal structure, fatty acid transfer protein (FATP) mRNA expression in the small intestine, and FA composition in the intestinal mucosa and breast muscle of broiler chickens compared with SBO.

\section{Methods}

\section{Experimental design, animals, and diets}

A total of 144 day-old Arbor Acres Plus male commercial broilers obtained from a commercial hatchery were randomly allocated to 12 pens. Each treatment was assigned to 6 replicates of 12 chicks, and broilers were fed a 2-phase diet with transition from starter ( 0 to $3 \mathrm{wk}$ ) to grower (4 to $6 \mathrm{wk}$ ). Starter diets were isoenergetically supplemented with $3.0 \% \mathrm{PF}$ or $2.7 \% \mathrm{SBO}$, and grower diets were isoenergetically supplemented with $3.8 \%$ PF or $3.5 \%$ SBO. Thus, the corn/soybean meal content varied between diets. The nutrient analyzed values met or exceeded the recommendations of NY/T33-2004. The composition of the experimental diet and FA compositions of the diets are presented in Table 1.

All birds were housed in the same experimental chicken house under $24 \mathrm{~h}$ continuous light. The environmental temperature was initially set at $33^{\circ} \mathrm{C}$ and then gradually reduced to $21^{\circ} \mathrm{C}$. All chickens had free access to water and the experimental diets. The present study was approved by the China Agricultural University and was carried out in accordance with the Guidelines for Experimental Animals.

\section{Tissue sampling and preparation}

At 2, 4, and 6 wk of age, six chicks from each treatment group were anesthetized by intravenous injection of sodium 75 pentobarbitone $(1 \mathrm{~mL} / \mathrm{kg} \mathrm{BW})$ after fasting for $6 \mathrm{~h}$. The intestine was removed and weighed. The jejunal mucosa near Meckel's diverticulum was removed by gentle scraping with a clean microscope slide, washed with cold phosphate buffered saline, frozen in liquid nitrogen, and stored at $-80^{\circ} \mathrm{C}$ for the determination of L-FABP and FATP mRNA levels and DNA, RNA, and protein concentrations. A $1 \mathrm{~cm}$ piece of jejunum near Meckel's diverticulum was removed and flushed with $0.9 \% \mathrm{NaCl}$ and then fixed in $10 \%$ neutral buffered formalin solution for morphometric analysis. Morphological observation was performed on $5 \mu \mathrm{m}$ sections under a light microscope (Nikon Eclipse TE2000-S) according to Sklan and Noy [13].

\section{DNA, RNA, and protein assay}

The RNA, DNA, and protein were extracted from segments frozen in liquid nitrogen using TRI Reagent RNA/DNA/ Protein Isolation Reagent (Invitrogen Life Technologies,
Carlsbad, CA), and mean concentrations were determined colorimetrically according to Uni et al. [14].

\section{Total RNA isolation and reverse transcription}

Total RNA was isolated from jejunal mucosa using TRIzol Reagent (1334257; Invitrogen Life Technologies, Carlsbad, CA) according to the manufacturer's instructions. RNA integrity was assessed via agarose gel electrophoresis, and RNA concentration and purity were determined spectrophotometrically using A260 and A280 measurements. Reverse transcription (RT) reactions $(20 \mu \mathrm{L})$ comprised $1 \mu \mathrm{g}$ total RNA, $20 \mathrm{U}$ of an RNAse inhibitor (Promega), $10 \mathrm{mmol} \mathrm{dNTPs} \mathrm{(Sigma),}$ 4.0 $\mu \mathrm{L}$ of $5 \times \mathrm{M}-\mathrm{MLV} \mathrm{RT}$ reaction buffer (Promega), $100 \mathrm{U}$ M-MLV transcriptase (Promega), and $1.0 \mu \mathrm{L}$ Oligo (dT) 12-18 (Promega). Cycle parameters for the RT procedure were 1 cycle at $20^{\circ} \mathrm{C}$ for $5 \mathrm{~min}, 1$ cycle at $42^{\circ} \mathrm{C}$ for $60 \mathrm{~min}$, and 1 cycle at $70^{\circ} \mathrm{C}$ for $5 \mathrm{~min}$. The reaction was stopped by placement on ice. The RT products (cDNA) were stored at $-20^{\circ} \mathrm{C}$ for relative gene abundance by PCR.

\section{Real-time PCR for abundance of L-FABP and FATP mRNA}

Quantitative analysis of PCR was performed with the PRISM 7700 Fluorescence Detection System (ABI Biosystems) according to optimized PCR protocols and the SYBR Green qPCR kit (ABI Biosystems 4309155), in which SYBR Green was a double-stranded, DNA-specific fluorescent dye. The PCR reaction system $(20 \mu \mathrm{L})$ contained $10 \mu \mathrm{L}$ SYBR Green PCR Master Mix, $2.0 \mu \mathrm{L}$ primer $(1.0 \mu \mathrm{L}$ forward and $1.0 \mu \mathrm{L}$ reverse; see Table 2 for primer sequence), and $2.0 \mu \mathrm{L}$ cDNA template. For the PCR reaction, the experimental protocol was as follows: denaturation program $\left(95^{\circ} \mathrm{C}\right.$ for $\left.3 \mathrm{~min}\right)$, amplification and abundance program repeated 42 times $\left(94^{\circ} \mathrm{C}\right.$ for $30 \mathrm{~s}, 51^{\circ} \mathrm{C}$ for $30 \mathrm{~s}$, and $72^{\circ} \mathrm{C}$ for $60 \mathrm{~s}$ with a single fluorescence measurement), and extension $\left(72^{\circ} \mathrm{C}\right.$ for $\left.7 \mathrm{~min}\right)$. Relative standard curve methods were used to calculate the abundance of gene expression. Briefly, copy numbers were determined from two independent cDNA preparations of any sample. Copy numbers were calculated relative to a dilution series of the respective reference plasmids, comprising 103 to 108 copies. The reference plasmids contained the cloned RT-PCR products obtained with these primers. The housekeeping gene, $\beta$-actin, was used as an internal standard for the PCR reaction.

\section{Assay of FA in jejunal mucosa and breast muscle}

The mucosa of the jejunum was removed by gentle scraping with a clean microscope slide at 6 wk of age, and together with breast muscle, was weighed and lyophilized. The FA compositions of jejunal mucosa, breast muscle, and diet were determined according to Sukhjja and Palmquist [15] with minor modifications. Samples 
Table 1 Composition ${ }^{1}$ of the experimental diet $(\mathrm{g} / 100 \mathrm{~g}$ of diet)

\begin{tabular}{|c|c|c|c|c|}
\hline \multirow[t]{2}{*}{ Ingredients } & \multicolumn{2}{|c|}{ Starter (0-3 wk) } & \multicolumn{2}{|c|}{ Grower (4-6 wk) } \\
\hline & $\begin{array}{l}\text { Poultry } \\
\text { fat }\end{array}$ & $\begin{array}{c}\text { Soybean } \\
\text { oil }\end{array}$ & $\begin{array}{c}\text { Poultry } \\
\text { fat }\end{array}$ & $\begin{array}{c}\text { Soybean } \\
\text { oil }\end{array}$ \\
\hline Corn & 54.75 & 55.12 & 59.10 & 59.50 \\
\hline Soybean meal & 38.17 & 38.10 & 33.50 & 33.40 \\
\hline Limestone & 1.20 & 1.20 & 1.20 & 1.20 \\
\hline Dicalcium phosphate & 1.90 & 1.90 & 1.60 & 1.60 \\
\hline Salt & 0.35 & 0.35 & 0.35 & 0.35 \\
\hline Soybean oil & 0.00 & 2.70 & 0.00 & 3.50 \\
\hline Poultry fat & 3.00 & 0.00 & 3.80 & 0.00 \\
\hline 98\% DL-methionine & 0.18 & 0.18 & 0.11 & 0.11 \\
\hline $4 \%$ flavomycin & 0.04 & 0.04 & 0.02 & 0.02 \\
\hline $33 \%$ ethoxyquin & 0.03 & 0.03 & 0.00 & 0.00 \\
\hline Trace mineral premix ${ }^{3}$ & 0.20 & 0.20 & 0.20 & 0.20 \\
\hline Vitamin Premix ${ }^{4}$ & 0.02 & 0.02 & 0.02 & 0.02 \\
\hline $50 \%$ choline chloride & 0.16 & 0.16 & 0.10 & 0.10 \\
\hline \multicolumn{5}{|l|}{ Calculated analysis $^{5}$} \\
\hline AME, kcal/kg & 2,910 & 2,910 & 3,000 & 3,000 \\
\hline Crude protein,\% & 20.68 & 20.68 & 19.00 & 19.00 \\
\hline Lysine,\% & 1.12 & 1.12 & 1.00 & 1.00 \\
\hline Methionine + cysteine,\% & 0.83 & 0.83 & 0.71 & 0.71 \\
\hline Calcium,\% & 0.98 & 0.98 & 0.90 & 0.90 \\
\hline Available phosphorus,\% & 0.45 & 0.45 & 0.40 & 0.40 \\
\hline \multicolumn{5}{|l|}{ Determined analysis } \\
\hline C14:0, mg/g & 0.13 & 0.04 & 0.19 & 0.05 \\
\hline $\mathrm{C} 14: 1, \mathrm{mg} / \mathrm{g}$ & 0.02 & $-{ }^{2}$ & 0.05 & - \\
\hline $\mathrm{C} 16: 0, \mathrm{mg} / \mathrm{g}$ & 10.14 & 6.35 & 12.83 & 7.33 \\
\hline C16:1, mg/g & 1.47 & 0.10 & 1.98 & 0.16 \\
\hline $\mathrm{C} 18: 0, \mathrm{mg} / \mathrm{g}$ & 2.12 & 1.58 & 2.81 & 1.91 \\
\hline C18:1, mg/g & 16.13 & 10.22 & 19.88 & 12.48 \\
\hline $\mathrm{C} 18: 2, \mathrm{mg} / \mathrm{g}$ & 18.88 & 23.87 & 20.67 & 28.67 \\
\hline $\mathrm{C} 18: 3, \mathrm{mg} / \mathrm{g}$ & 1.07 & 2.12 & 1.12 & 2.60 \\
\hline $\mathrm{C} 20: 0, \mathrm{mg} / \mathrm{g}$ & 0.13 & 0.20 & 0.17 & 0.23 \\
\hline $\mathrm{C} 20: 1, \mathrm{mg} / \mathrm{g}$ & 0.19 & 0.15 & 0.25 & 0.19 \\
\hline $\mathrm{C} 20: 2, \mathrm{mg} / \mathrm{g}$ & 0.05 & 0.02 & 0.06 & 0.02 \\
\hline $\mathrm{C} 20: 3, \mathrm{mg} / \mathrm{g}$ & 0.04 & - & 0.05 & - \\
\hline $\mathrm{C} 22: 0, \mathrm{mg} / \mathrm{g}$ & 0.17 & 0.53 & 0.17 & 0.32 \\
\hline C22:1, mg/g & 0.06 & 0.14 & 0.11 & 0.17 \\
\hline $\mathrm{C} 24: 0, \mathrm{mg} / \mathrm{g}$ & 0.03 & 1.61 & 0.10 & 2.45 \\
\hline SFA, mg/g & 12.72 & 10.31 & 16.27 & 11.06 \\
\hline MUFA, mg/g & 17.87 & 10.61 & 22.27 & 13.00 \\
\hline PUFA, mg/g & 20.04 & 26.03 & 21.90 & 31.29 \\
\hline Total FA, mg/g & 50.63 & 46.95 & 60.44 & 55.35 \\
\hline SFA, \% & 25.12 & 21.96 & 26.92 & 19.98 \\
\hline MUFA, \% & 35.30 & 22.60 & 36.85 & 23.49 \\
\hline
\end{tabular}

Table 1 Composition ${ }^{1}$ of the experimental diet $(\mathrm{g} / 100 \mathrm{~g}$ of diet) (Continued)

\begin{tabular}{lcccc}
\hline PUFA, \% & 39.58 & 55.44 & 36.23 & 56.53 \\
MUFA/SFA & 1.41 & 1.03 & 1.37 & 1.18 \\
PUFA/SFA & 1.58 & 2.52 & 1.35 & 2.83 \\
\hline
\end{tabular}

${ }^{1}$ Data are expressed on an as-fed basis.

${ }^{2}$ Undetermined.

${ }^{3}$ Trace mineral premix provided per kilogram of diet: $\mathrm{Fe}, 80 \mathrm{mg}$ (as $\mathrm{FeSO}_{4} \cdot \mathrm{H}_{2} \mathrm{O}$ ); $\mathrm{Cu}, 8 \mathrm{mg}$ (as $\mathrm{CuSO}_{4} \cdot 5 \mathrm{H}_{2} \mathrm{O}$ ); $\mathrm{Zn}, 100 \mathrm{mg}$ (as $\mathrm{ZnSO}_{4} \cdot \mathrm{H}_{2} \mathrm{O}$ ); $\mathrm{Mn}, 100 \mathrm{mg}$ (as $\mathrm{MnSO}_{4} \cdot \mathrm{H}_{2} \mathrm{O}$ ); $\mathrm{Se}, 0.3 \mathrm{mg}\left(\right.$ as $\left.\mathrm{Na}_{2} \mathrm{SeO}_{3}\right) ; \mathrm{I}, 0.50 \mathrm{mg}$ (as $\mathrm{Ca}\left(\mathrm{IO}_{3}\right)_{2}$.

${ }^{4}$ Vitamin premix provided per kilogram of diet: Vitamin $\mathrm{A}$ (as retinyl acetate), 12,500 IU; cholecalciferol, 2,500 IU; vitamin E (as dl-a-tocopherol acetate), $18 \mathrm{IU}$; menadione, $3 \mathrm{mg}$; thiamine, $2.5 \mathrm{mg}$; riboflavin, $6.6 \mathrm{mg}$; pyridoxine, $4.9 \mathrm{mg}$; pantothenic acid, $14.7 \mathrm{mg}$; niacin, $36.8 \mathrm{mg}$; folic acid, $1.2 \mathrm{mg}$; biotin, $0.013 \mathrm{mg}$; cobalamine, $0.025 \mathrm{mg}$.

${ }^{5}$ Calculated value.

containing 10 to $50 \mathrm{mg}$ of lipids were accurately weighed, and $4 \mathrm{~mL}$ of $\mathrm{n}$-hexane containing internal standard (heptadecanoic acid, C17:0, Fluka 51633) and $3 \mathrm{~mL}$ of freshly made $5 \%$ methanolic $\mathrm{HCl}$ were added and heated for $2 \mathrm{~h}$ in a water bath at $80^{\circ} \mathrm{C}$ to methylate. The FA content was determined using a gas chromatograph HP 6890 equipped with a flame ionization detector and an HP-INNOWA capillary column. Helium was used as the carrier gas. The oven temperature was programmed as follows: from $140^{\circ} \mathrm{C}$ to $200^{\circ} \mathrm{C}$ at $1.50^{\circ} \mathrm{C} /$ $\mathrm{min}$; from $200^{\circ} \mathrm{C}$ to $220^{\circ} \mathrm{C}$ at $100^{\circ} \mathrm{C} / \mathrm{min}$; and from $220^{\circ} \mathrm{C}$ to $230^{\circ} \mathrm{C}$ at $20^{\circ} \mathrm{C} / \mathrm{min}$. The other chromatographic conditions were: injector and detector temperatures, $200^{\circ} \mathrm{C}$; and injected sample volume, $1 \mu \mathrm{L}$. FA were identified by matching their retention times with those of their relative standards.

\section{Statistical analysis}

The data were compared using SPSS 10.0 with an independent-samples $t$-test, and a $P$-value of $<0.05$ was considered statistically significant.

\section{Results}

Intestinal development

PF had no influence on the weight of the jejunum or the villus height, crypt depth, or villus height/crypt depth of the jejunal mucosa compared with SBO in broilers with mean BW to each age (data not shown). DNA, RNA, and protein concentrations in jejunal mucosa were comparable in PF- and SBO-fed birds.

\section{L-FABP and FATP mRNA abundance}

PF had no influence on L-FABP $(P=0.79)$ or FATP $(P=0.23)$ mRNA abundance of jejunal mucosa at $2 \mathrm{wk}$ of age, and there was no difference in L-FABP mRNA abundance at $4 \mathrm{wk}$ of age $(P=0.26)$ (Table 3$)$. However, compared with SBO, PF significantly decreased FATP mRNA abundance at $4 \mathrm{wk}(P=0.009)$ and $6 \mathrm{wk}$ of age 
Table 2 Oligonucleotide PCR primers

\begin{tabular}{|c|c|c|c|c|}
\hline Name & Oligo & Primer sequence & Predicted size (bp) & GenBank accession \\
\hline L-FABP & ForwardReverse & 5'-GAAGGGTAAGGACATCAA-3'5'-TCGGTCACGGATITCAGC-3' & 219 & NM_204192 \\
\hline FATP-1 & ForwardReverse & 5'-GACTGCGCCAAGTACAGATGC-3'5'-CACTCGGTGGCTCCGTAGAAC-3' & 203 & DQ352834 \\
\hline$\beta$-actin & ForwardReverse & 5'-CCACCGCAAATGCTTCTAAAC-3'5'-AAGACTGCTGCTGACACCTTC-3' & 175 & NM_205518 \\
\hline
\end{tabular}

$(P<0.001)$ and significantly decreased L-FABP mRNA abundance at 6 wk of age $(P=0.039)$.

\section{FA composition of intestinal mucosa and breast muscle}

In the jejunal mucosa, PF decreased the content of $\mathrm{C} 18: 2$ $(P=0.015), \quad C 18: 3 \quad(P<0.001), \quad C 20: 2 \quad(P=0.018)$, and $\Sigma$ PUFA $(P<0.020)$; the proportion of PUFA $(P<0.001)$; and the ratio of PUFA/SFA $(P=0.006)$ compared with SBO at $6 \mathrm{wk}$ of age (Table 4). However, PF significantly increased the content of $\mathrm{C} 24: 0(P=0.008)$ and the proportion $(\%)$ of SFA $(P=0.024)$ and monounsaturated FA (MUFA) $(P<0.001)$.

In the breast muscle of broilers at 6 wk of age, PF decreased the content of C18:2 $(P=0.010), \quad \mathrm{C} 18: 3$ $(P<0.001), C 20: 2(P<0.001)$, and $\Sigma$ PUFA $(P=0.005)$; the proportion $(\%)$ of PUFA $(P<0.001)$; and the ratio of PUFA/ SFA $(P<0.001)$. However, PF increased the content of C16:1 $(P=0.021)$ and $C 20: 1(P=0.029)$; the proportion (\%) of MUFA $(P<0.001)$; and the ratio of MUFA/SFA $(P<0.001)$.

\section{Discussion}

In the current study, PF supplementation had no influence on the weight of the jejunum, villus height, crypt depth, or villus height/crypt depth compared with SBO in broilers of different ages. A previous study in rodents showed that different sources of dietary fat had different effects on the intestinal morphology of rats. Corn oil and olive oil significantly increased the villus height in both the jejunum and ileum, and olive oil markedly decreased the crypt depth in the jejunum and ileum. However, beef tallow (BT) markedly reduced the villus height and crypt depth in both the jejunum and ileum [3]. Dänicke et al. [16] showed that the viscosity of digestive contents could induce morphological and physiological changes in the intestine, and the inhibitory effect of BT on the

Table 3 L-FABP and FATP mRNA abundance

\begin{tabular}{llllll}
\hline Age & mRNA & Poultry fat & Soybean oil & SEM & $P$ value \\
\hline $2 w k$ & L-FABP & 0.078 & 0.083 & 0.010 & 0.791 \\
& FATP & 0.32 & 0.40 & 0.034 & 0.233 \\
\multirow{2}{*}{$4 w k$} & L-FABP & 0.21 & 0.28 & 0.029 & 0.260 \\
& FATP & 0.58 & 1.66 & 0.211 & 0.009 \\
$6 w k$ & L-FABP & 0.05 & 0.15 & 0.019 & 0.039 \\
& FATP & 0.38 & 2.33 & 0.339 & $<0.001$ \\
\hline
\end{tabular}

development of intestinal villi attributed to a greater increase in the viscosity of jejunal and ileal contents compared with SBO. Because PF is rich in MUFA (oleic, 39.5\%) and PUFA (linoleic, 23.5\%) and relatively lower in SFA (palmitic, 21.4\%) compared with BT and lard, PF appeared to be more efficiently utilized than other animal fats [8]. A previous study showed that supplemental $\mathrm{PF}$ at $0 \%, 5 \%, 10 \%$, and $20 \%$ did not change the transition time in the gastrointestinal tract [17], which indicates that PF supplementation did not affect the viscosity of digestive contents. Therefore, in the present study, the similar viscosity of digestive contents between approximately $3 \%$ to $4 \%$ of PF supplementation and SBO supplementation may have resulted in no difference in the small intestinal morphology.

Furthermore, our results showed that PF did not affect DNA, RNA, or protein concentrations compared with SBO. Uni et al. [18] showed that RNA/DNA, RNA/protein, and protein/DNA indicated tissue activity, ribosomal capacity, and cell size, respectively. Dänicke et al. [16] showed that morphological changes in the intestine mediated by fat type might be associated with intestinal protein synthesis. In the current study, the mucosal characteristics were consistent with the intestinal weight. The results indicated that PF had no negative effect on tissue activity, ribosomal capacity, cell size, or intestinal protein synthesis compared with SBO and suggested that PF had no effect on the development of the intestinal structure at a $3 \%$ to $4 \%$ supplementation level.

Kaur et al. [19] and Ferrer et al. [4] showed that coconut oil increased the level of SFA in the brush border membrane and that corn oil increased the proportion of linoleic acid and arachidonic acid. In the current study, PF significantly decreased the content of PUFA and significantly increased the proportion of SFA and MUFA in the jejunal mucosa. This was in agreement with previous studies showing that the dietary FA composition influenced the intestinal brush border FA composition.

In the current study, PF significantly decreased FATP mRNA and L-FABP mRNA abundance at 4 or 6 wk of age compared with SBO. FATP, which is thought to be involved in both the movement of long-chain FA across the plasma membrane and esterification [20], was proposed as a major FA transporter in intestinal lipid absorption. L-FABP played a key role in transporting FA through the cytosol of absorptive cells [21]. A previous study showed that L-FABP has a higher affinity for 
Table 4 Fatty acid concentration of intestinal mucosa and breast muscle (fresh) of broilers at 6 wk of age

\begin{tabular}{|c|c|c|c|c|c|c|c|c|}
\hline \multirow[t]{2}{*}{ Fatty acid } & \multicolumn{4}{|c|}{ Intestinal mucosa } & \multicolumn{4}{|c|}{ Breast muscle } \\
\hline & Poultry fat & Soybean oil & SEM & $P$ value & Poultry fat & Soybean oil & SEM & $P$ value \\
\hline $\mathrm{C} 14: 0, \mathrm{mg} / \mathrm{g}$ & 0.11 & 0.08 & 0.013 & 0.193 & 0.04 & 0.03 & 0.006 & 0.385 \\
\hline $\mathrm{C} 14: 1, \mathrm{mg} / \mathrm{g}$ & 0.03 & 0.02 & 0.005 & 0.125 & 0.08 & 0.08 & 0.002 & 0.707 \\
\hline $\mathrm{C} 16: 0, \mathrm{mg} / \mathrm{g}$ & 4.85 & 4.31 & 0.511 & 0.535 & 2.19 & 1.93 & 0.128 & 0.348 \\
\hline $\mathrm{C} 16: 1, \mathrm{mg} / \mathrm{g}$ & 0.91 & 0.46 & 0.128 & 0.077 & 0.36 & 0.21 & 0.047 & 0.021 \\
\hline $\mathrm{C} 18: 0, \mathrm{mg} / \mathrm{g}$ & 3.58 & 3.73 & 0.243 & 0.488 & 1.03 & 1.05 & 0.038 & 0.833 \\
\hline $\mathrm{C} 18: 1, \mathrm{mg} / \mathrm{g}$ & 6.24 & 4.32 & 0.762 & 0.160 & 3.08 & 2.23 & 0.266 & 0.113 \\
\hline $\mathrm{C} 18: 2, \mathrm{mg} / \mathrm{g}$ & 5.86 & 8.24 & 0.636 & 0.015 & 1.83 & 2.60 & 0.164 & 0.010 \\
\hline $\mathrm{C} 18: 3, \mathrm{mg} / \mathrm{g}$ & 0.18 & 0.45 & 0.044 & $<0.001$ & 0.05 & 0.14 & 0.015 & $<0.001$ \\
\hline $\mathrm{C} 20: 0, \mathrm{mg} / \mathrm{g}$ & 0.07 & 0.07 & 0.009 & 0.439 & 0.01 & 0.01 & 0.001 & 1.000 \\
\hline $\mathrm{C} 20: 1, \mathrm{mg} / \mathrm{g}$ & 0.10 & 0.09 & 0.013 & 0.746 & 0.05 & 0.03 & 0.004 & 0.029 \\
\hline $\mathrm{C} 20: 2, \mathrm{mg} / \mathrm{g}$ & 0.08 & 0.12 & 0.010 & 0.018 & 0.07 & 0.11 & 0.007 & $<0.001$ \\
\hline $\mathrm{C} 20: 3, \mathrm{mg} / \mathrm{g}$ & 1.27 & 1.01 & 0.107 & 0.137 & 0.61 & 0.69 & 0.022 & 0.056 \\
\hline $\mathrm{C} 22: 0, \mathrm{mg} / \mathrm{g}$ & 0.43 & 0.42 & 0.064 & 0.436 & 0.09 & 0.08 & 0.007 & 0.345 \\
\hline $\mathrm{C} 24: 0, \mathrm{mg} / \mathrm{g}$ & 0.43 & 0.25 & 0.076 & 0.008 & 0.08 & 0.19 & 0.030 & 0.075 \\
\hline$\Sigma \mathrm{SFA}, \mathrm{mg} / \mathrm{g}$ & 9.36 & 8.66 & 0.717 & 0.687 & 3.40 & 3.26 & 0.159 & 0.680 \\
\hline$\Sigma M U F A, m g / g$ & 7.28 & 4.89 & 0.899 & 0.145 & 3.51 & 2.56 & 0.315 & 0.089 \\
\hline$\Sigma P U F A, m g / g$ & 7.40 & 9.82 & 0.676 & 0.020 & 2.56 & 3.54 & 0.196 & 0.005 \\
\hline$\Sigma \mathrm{FA}, \mathrm{mg} / \mathrm{g}$ & 24.04 & 23.37 & 1.704 & 0.854 & 9.48 & 9.36 & 0.506 & 0.916 \\
\hline SFA, $\%$ & 39.27 & 37.16 & 0.814 & 0.024 & 36.15 & 34.89 & 0.455 & 0.124 \\
\hline MUFA, \% & 29.48 & 20.71 & 1.687 & $<0.001$ & 36.62 & 27.21 & 1.669 & $<0.001$ \\
\hline PUFA, \% & 31.25 & 42.13 & 1.040 & $<0.001$ & 27.24 & 37.90 & 1.720 & $<0.001$ \\
\hline MUFA/SFA & 0.75 & 0.56 & 0.040 & $<0.001$ & 1.02 & 0.78 & 0.042 & $<0.001$ \\
\hline PUFA/SFA & 0.80 & 1.13 & 0.052 & 0.006 & 0.75 & 1.09 & 0.053 & $<0.001$ \\
\hline
\end{tabular}

polyunsaturated long-chain FA [22]. Oleic acid increased the L-FABP mRNA abundance in the small intestine of rats with a lower efficiency than that of linoleic acid [12]. In the current study, PF diet had a lower PUFA concentration than that of $\mathrm{SBO}$, which might be the reason that PF significantly decreased FATP and L-FABP mRNA abundance. However, there was no significant difference in FATP and L-FABP mRNA abundance between PF and SBO when chickens were 2 wk of age. A previous study indicated that the ability to utilize and absorb fats, especially animal fats, was low in young poultry and was improved with increasing age; the concentrations of FABP declined from those in newly hatched chicks, but increased again after 3 wk of age, and increased significantly between 4 and 6 wk of age [23]. In our study, the lack of a difference in the abundance of L-FABP and FATP mRNA between the PF and SBO diets at 2 wk of age might have been due to the age of the chicks.

Previous studies confirmed that dietary FA composition affected the FA composition of breast muscle [24]. In the current study, our results agreed with those of Apple et al. [25], who showed that pigs fed an SBO diet had significantly reduced MUFA percentages and increased PUFA percentages and PUFA/SFA ratios compared with pigs fed a PF diet. It seemed that the dietary FA composition had similar effects on the breast muscle of both pigs and poultry. The fact that PF decreased the PUFA content in the breast muscle might be related to the lower L-FABP and FATP mRNA abundance in the jejunal mucosa compared with SBO. Because PUFA can be easily oxidated when heated, it produces various volatile compounds, including the aldehydes pentanal and hexanal, thus influencing the meat flavor [26]. In the current study, PF significantly decreased the PUFA content, especially linoleic acid and linolenic acid, the main PUFA in chicken breasts [27]. This indicates that PF might have a negative effect on the meat flavor of poultry, although this requires further confirmation.

\section{Conclusions}

PF had no influence on intestinal development. However, PF decreased FATP and L-FABP mRNA expression in the later growth period and decreased the content of PUFA, especially linoleic acid and linolenic acid, and the 
PUFA/SFA ratios in breast muscle of chickens compared with SBO.

\section{Competing interests}

The authors declare that they have no competing interests.

\section{Acknowledgments}

This research was supported by funds from the Yangtze River Scholar and Innovation Research Team Development Program, Project No. IRT0945.

\section{Authors' contributions}

Jianmin Yuan conceived of the study, and carried out the animal trail, finished the statistical analysis and drafted the manuscript. Binkun Zhang participated in tissue sampling and molecular genetic studies. Yuming Guo was supervision of the research group, and supplied the funding. All authors read and approved the final manuscript.

\section{Authors' information}

Dr. Jianmin Yuan, associate professor of China Agricultural University, Focus on development of constructure and function of digestive organ, and modification of product quality in poultry.

Received: 17 January 2012 Accepted: 16 May 2012

Published: 16 May 2012

\section{References}

1. Van Leeuwen P, Mouwen JM, van der Klis JD, Verstegen MW: Morphology of the small intestinal mucosal surface of broilers in relation to age, diet formulation, small intestinal microflora and performance. Br Poult Sci 2004, 45:41-48.

2. Thomson AB, Keelan M, Clandinin MT, Rajotte RV, Cheeseman C, Walker K: Use of polyunsaturated diet to treat the enhanced intestinal uptake of lipids in streptozotocin diabetic rats. Clin Invest Med 1988, 11:57-61.

3. Sagher FA, Dodge JA, Johnston CF, Shaw C, Buchanan KD, Carr KE: Rat small intestinal morphology and tissue regulatory peptides: effects of high dietary fat. Br J Nutr 1991, 65:21-28.

4. Ferrer C, Pedragosa M, Torras-Llort X, Parcerisa M, Rafecas R, Ferrer C, Amat MM: Dietary lipids modify brush border membrane composition and nutrient transport in chicken small intestine. J Nutr 2003, 133:1147-1153.

5. Lindley KJ, Muller DP, Milla PJ: Effects of dietary polyunsaturated fatty acids on small intestinal secretory and absorptive function: studies in rat jejunum in vitro. Clin Sci 1995, 88:219-224.

6. Vazquez CM, Rovira N, Ruiz-Gutierrez V, Planas JM: Developmental changes in glucose transport, lipid composition, and fluidity of jejunal BBM. Am J Physiol 1997, 273:R1086-R1093.

7. Thomson AB, Keelan M, Clandinin MT, Walker K: Dietary fat selectively alters transport properties of rat jejunum. J Clin Invest 1986, 77:279-288.

8. Fuller $\mathrm{HL}$, Rendon $\mathrm{M}$ : Energetic efficiency of different dietary fats for growth of young chicks. Poult Sci 1977, 56:549-557.

9. Apple JK, Maxwell CV, Galloway DL, Hutchison S, Hamilton CR: Interactive effects of dietary fat source and slaughter weight in growing-finishing swine: i. growth performance and longissimus muscle fatty acid composition. J Anim Sci 2009a, 87:1407-1422.

10. Seerley RW, Briscoe JP, Mccampbell HC: Comparison of poultry and animal fat on performance - body-composition and tissue-lipids of swine. J Anim Sci 1978, 46:1018-1023.

11. Yuan JM, Guo YM, Yang Y, Wang ZH: Characterization of fatty acid digestion of Beijing Fatty Chickens and Arbor Acres Chickens. Asian-Aust J Anim Sci 2007, 20:1222-1228.

12. Poirier H, Niot I, Degrase P, Monnot MC, Bernard A, Besnard P: Fatty acid regulation of fatty acid-binding protein expression in the small intestine. Am J Physiol 1997, 273:G289-G295.

13. Sklan D, Noy Y: Functional development and intestinal absorption in the young poult. Br Poult Sci 2003, 44:651-658.

14. Uni Z, Ganot S, Sklan D: Posthatch development of mucosal function in the broiler small intestine. Poult Sci 1998, 77:75-82.

15. Sukhija PS, Palmquist DL: Rapid method for determination of total fattyacid content and composition of feedstuffs and feces. J Agri Food Chem 1988, 36:1202-1206.
16. Dänicke S, Böttcher W, Jeroch H, Thielebein J, Simon O: Replacement of soybean oil with tallow in rye-based diets without xylanase increases protein synthesis in small intestine of broilers. J Nutr 2000, 130:827-834.

17. Golian A, Maurice DV: Dietary poultry fat and gastrointestinal transit time of feed and fat utilization in broiler chickens. Poult Sci 1992, 71:1357-1363

18. Uni Z, Noy Y, Sklan D: Development of the small intestine in heavy and light strain chicks before and after hatching. Br Poult Sci 1996, 37:63-71.

19. Kaur M, Kaur J, Ojha S, Mahmood A: Dietary fat effects on brush border membrane composition and enzyme activities in rat intestine. Ann Nutr Metab 1996, 40:269-276.

20. Coe NR, Smith AJ, Frohnert BI, Watkins PA, Bernlohr DA: The fatty acid transport protein (fatp1) is a very long chain acyl-coa synthetase. J Biol Chem 1999, 274:36300-36304.

21. Krogdahl A: Digestion and absorption of lipids in poultry. J Nutr 1985, 115:675-685.

22. Richieri GV, Ogata RT, Kleinfeld AM: Fatty acid interactions with native and mutant fatty acid binding protein. Mol Cell Biochem 1999, 192:77-85.

23. Katongole JBD, March BE: Fat utilization in relation to intestinal fatty acid binging protein and bile salts in chicks of different ages and different genetic sources. Poult Sci 1980, 59:819-827.

24. Ferrini G, Baucells MD, Esteve-Garcia E, Barroeta AC: Dietary polyunsaturated fat reduces skin fat as well as abdominal fat in broiler chickens. Poult Sci 2008, 87:528-535.

25. Apple JK, Maxwell CV, Galloway DL, Hamilton CR, Yancey JW: Interactive effects of dietary fat source and slaughter weight in growing-finishing swine: iii. carcass and fatty acid compositions. J Anim Sci 2009b, 87:1441-1454.

26. Ganderemer G: Lipids in muscles and adipose tissues, change during processing and sensory properties of meat products. Meat Sci 2002, 62:309-321.

27. Jahan K, Paterson A, Piggott J, Spickett C: Chemometric modeling to relate antioxidants, neutral lipid fatty acids, and flavour components in chicken breasts. Poult Sci 2005, 84:158-166.

doi:10.1186/2049-1891-3-17

Cite this article as: Yuan et al.: Poultry fat decreased fatty acid transporter protein mRNA expression and affected fatty acid composition in chickens. Journal of Animal Science and Biotechnology 2012 $3: 17$.

\section{Submit your next manuscript to BioMed Central and take full advantage of:}

- Convenient online submission

- Thorough peer review

- No space constraints or color figure charges

- Immediate publication on acceptance

- Inclusion in PubMed, CAS, Scopus and Google Scholar

- Research which is freely available for redistribution 